\title{
IMPACT OF LONG-TERM AGEING ON $\sigma$ PHASE PRECIPITATION PROCESS IN STEELS WITH AUSTENITIC MATRIX
}

\author{
WPŁYW DŁUGOTRWAŁEGO STARZENIA NA PROCES WYDZIELENIOWY FAZY $\sigma$ \\ W STALACH O OSNOWIE AUSTENITYCZNEJ
}

\begin{abstract}
Super 304H, HR3C and Sanicro 25 grade austenitic matrix steels are used in the construction of pressure components of boilers with supercritical operating parameters. The article presents the results of microstructure examination in delivery condition and after ageing for up to 50,000 hours at $700^{\circ} \mathrm{C}$. The microstructure examination was performed using scanning and transmission electron microscopy. The precipitates were identified using transmission electron microscopy. In particular, the study analysed the $\sigma$ phase precipitation process and its dynamics depending on the ageing time. It has been shown that the intermetallic $\sigma$ phase plays a significant role in the loss of durability of the tested steel. It is related to its significant increase due to the influence of high temperature, and its coagulation and coalescence dynamics strongly depend on the ageing/operating temperature level. The qualitative and quantitative identification of the intermetallic $\sigma$ phase precipitation process described in the study is important in the analysis of the loss of durability of the tested steels under creep conditions.
\end{abstract}

Keywords: Super 304H, HR3C, Sanicro 25, microstructure, $v$ phase, ageing, loss of durability
Stale o osnowie austenitycznej w gatunkach Super 304H, HR3C i Sanicro 25 stosowane sa $w$ budowie elementów ciśnieniowych kottów o nadkrytycznych parametrach pracy. W pracy zaprezentowano wyniki badań mikrostruktury $w$ stanie dostawy oraz po starzeniu do 50000 godzin w temperaturze $700^{\circ} \mathrm{C}$. Badania mikrostruktury wykonano wykorzystujac skaningowa i transmisyjna mikroskopię elektronowa. Identyfikację występujących wydzieleń przeprowadzono przy użyciu transmisyjnej mikroskopii elektronowej. $W$ pracy $w$ szczególności analizowano proces wydzieleniowy fazy $\sigma$ i jego dynamike $w$ zależności od czasu starzenia. Pokazano, że międzymetaliczna faza $\sigma$ odgrywa istotny wptyw na utrate trwatości badanej stali. Zwiazane jest to z jej znacznym wzrostem wskutek oddziaływania wysokiej temperatury, a jej dynamika koagulacji i koalescencji zależy silnie od poziomu temperatury starzenia/eksploatacji. Identyfikacja jakościowa i ilościowa opisanego $w$ pracy procesu wydzieleniowego międzymetalicznej fazy $\sigma$ ma istotne znaczenie $w$ analizie utraty trwatości badanych stali $w$ warunkach petzania.

Stowa kluczowe: Super 304H, HR3C, Sanicro 25, mikrostruktura, faza $\sigma$, starzenie, utrata trwatości

\section{INTRODUCTION}

At the turn of 2000, the domestic power industry adopted a programme of thorough modernisation of the Polish power industry, including investments in the construction of supercritical boilers with an efficiency of 42-46\% [1]. This resulted in the commencement of extensive research on materials intended for operation at elevated and high temperatures, which lead to gaining experience in their selection and use [1-6]. These tests verified the required level of their strength and technological properties during longterm operation.

The group of materials most often used for components of supercritical boilers operating in the most difficult temperature and stress conditions include steels with a ferritic matrix from the $2.5 \% \mathrm{Cr}, 9-12 \% \mathrm{Cr}$ group and austenitic steels from the $18 \mathrm{Cr}-10 \mathrm{Ni}, 25 \mathrm{Cr}-20 \mathrm{Ni}$ group $[1,7]$.

The introduction of a new material grade to the power industry must be preceded by a series of long-term studies [7-9]. This requires thorough testing in laboratory and industrial conditions.
One of the basic criteria determining the suitability of the use of a given material for a boiler's pressure components is the stability of its microstructure and mechanical properties at the assumed temperature of expected operation $[7,10,11]$. This stability can be determined by applying long-term ageing to simulate operating parameters [6, 7]. Long-term ageing is one of the main methods of simulating the operating conditions of materials used at elevated and high temperatures $[7,8,12]$. This process is carried out at a temperature close to the temperature of the expected operation for at least tens of thousands of hours. In austenitic steels, it causes an improvement in strength properties and a reduction in plastic properties in the initial period $[6,8$, 13]. At the same time, increasing the ageing temperature to a level not exceeding $50-100^{\circ} \mathrm{C}$ of the maximum longterm operating temperature contributes to increasing the dynamics of the processes taking place.

In austenitic steels, the main strengthening mechanisms influencing the functional properties include solutionisation, precipitation hardening and strengthening with grain boundaries. In the case of use of austenitic steels at ele- 
Table 1. Chemical composition of the Super 304H steel, [weight \%]

Tabela 1. Skład chemiczny stali Super 304H, [\% masy]

\begin{tabular}{|c|c|c|c|c|c|c|c|c|c|c|c|c|}
\hline & \multicolumn{12}{|c|}{ Chemical composition, [weight \%] } \\
\hline & C & Si & Mn & $\mathbf{P}$ & $\mathbf{S}$ & $\mathbf{C u}$ & $\mathbf{C r}$ & Ni & $\mathbf{N b}$ & B & $\mathbf{N}$ & Al \\
\hline As delivered & 0.09 & 0.20 & 0.80 & 0.003 & 0.001 & 2.99 & 18.40 & 8.80 & 0.48 & 0.004 & 0.11 & 0.006 \\
\hline VDTÜV 550:12. 2012 & $\begin{array}{l}0.07 \\
0.13\end{array}$ & $\begin{array}{c}\max . \\
0.30\end{array}$ & $\begin{array}{c}\max . \\
1.00\end{array}$ & $\begin{array}{l}\max . \\
0.040\end{array}$ & $\begin{array}{l}\max . \\
0.010\end{array}$ & $\begin{array}{l}2.50 \\
3.50\end{array}$ & $\begin{array}{l}17.0 \\
19.0\end{array}$ & $\begin{array}{c}7.5 \\
10.5\end{array}$ & $\begin{array}{l}0.30 \\
0.60\end{array}$ & $\begin{array}{l}0.001 \\
0.010\end{array}$ & $\begin{array}{l}0.05 \\
0.12\end{array}$ & $\begin{array}{l}0.003 \\
0.030\end{array}$ \\
\hline
\end{tabular}

Table 2. Chemical composition of the tested HR3C steel, [weight \%]

Tabela 2. Skład chemiczny badanej stali HR3C, [\% masy]

\begin{tabular}{|c|c|c|c|c|c|c|c|c|c|}
\hline & \multicolumn{9}{|c|}{ Chemical composition, [weight \%] } \\
\hline & C & Si & Mn & $\mathbf{P}$ & $\mathbf{S}$ & Cr & Ni & Nb & $\mathbf{N}$ \\
\hline As delivered & 0.06 & 0.39 & 1.15 & 0.013 & 0.002 & 18.41 & 20.15 & 0.47 & 0.23 \\
\hline Vd TUV546 & $\begin{array}{c}\max . \\
0.10\end{array}$ & $\begin{array}{c}\max . \\
1.50\end{array}$ & $\begin{array}{c}\max . \\
2.00\end{array}$ & $\begin{array}{c}\max . \\
0.03\end{array}$ & $\begin{array}{c}\max . \\
0.03\end{array}$ & $\begin{array}{l}23.00 \\
27.00\end{array}$ & $\begin{array}{l}17.00 \\
23.00\end{array}$ & $\begin{array}{l}0.20 \\
0.35\end{array}$ & $\begin{array}{l}0.15 \\
0.35\end{array}$ \\
\hline
\end{tabular}

Table 3. Chemical composition of the tested Sanicro25 steel, [weight \%]

Tabela 3. Skład chemiczny badanej stali Sanicro25, [\% masy]

\begin{tabular}{|c|c|c|c|c|c|c|c|c|c|c|c|c|c|}
\hline & \multicolumn{13}{|c|}{ Chemical composition, weight \% } \\
\hline & C & Si & Mn & $\mathbf{P}$ & $\mathbf{S}$ & $\mathbf{C u}$ & $\mathrm{Cr}$ & Ni & $\mathbf{W}$ & Co & Nb & B & $\mathbf{N}$ \\
\hline As delivered & 0.06 & 0.25 & 0.50 & 0.01 & $<0.01$ & 2.9 & 23.0 & 24.1 & 3.2 & 1.4 & 0.4 & 0.005 & 0.17 \\
\hline VDTÜV 555:09.2008 & $\begin{array}{c}\max . \\
0.11\end{array}$ & $\begin{array}{c}\max . \\
0.40\end{array}$ & $\begin{array}{c}\max . \\
0.60\end{array}$ & $\begin{array}{l}\max . \\
0.025\end{array}$ & $\begin{array}{l}\max . \\
0.015\end{array}$ & $\begin{array}{l}2.0 \\
3.5\end{array}$ & $\begin{array}{l}21.5 \\
23.5\end{array}$ & $\begin{array}{l}23.5 \\
26.5\end{array}$ & $\begin{array}{l}2.0 \\
4.0\end{array}$ & $\begin{array}{l}1.0 \\
2.0\end{array}$ & $\begin{array}{l}0.30 \\
0.60\end{array}$ & $\begin{array}{l}\max . \\
0.008\end{array}$ & $\begin{array}{l}0.15 \\
0.30\end{array}$ \\
\hline
\end{tabular}

vated and high temperatures, due to the depletion of the matrix in alloying elements as a result of the precipitation and growth of secondary phases, as well as the reduction of dislocation blocking capacity by substitution elements, the main mechanism is precipitation strengthening, which significantly affects their heat resistance. Hence, the mechanisms of degradation of the microstructure of austenitic steels, which negatively affect their functional properties (creep strength, mechanical properties, corrosion resistance) in long-term operation, are the processes of precipitation of secondary phases, change of their morphology, the process of their spheroidisation and coagulation, depletion of the matrix in alloying elements as well as matrix softening processes [8].

$\mathrm{MX}, \mathrm{M}_{23} \mathrm{C}_{6}, \mathrm{M}_{6} \mathrm{X}, \mathrm{Z}$ phase ( $\left.\mathrm{NbCrN}\right)$ carbides/nitrides, intermetallic phases $\sigma$, Laves, $\mathrm{G}$ and $\chi$ and the copper-rich $\varepsilon_{-} \mathrm{Cu}$ phase are the most common precipitates in austenitic steels $[6,8]$. Their type of occurrence, morphology and volume fraction strongly depend on the chemical composition and operating parameters, and the knowledge of their stability is an indispensable element in the assessment of the functional properties of components operating under creep conditions. Literature data and own research clearly indicate that the phases which are most prone to growth and coalescence have a decisive influence on the loss of service life of steels intended for operating under creep conditions $[1,7,8]$.

This phase includes the intermetallic $\sigma$ phase crystallising in a tetragonal lattice in the temperature range of 600 to $1000^{\circ} \mathrm{C}[8,14,15]$. The places which are particularly privileged to its precipitation are the points of contact of three grains and $\delta$ ferrite precipitates [8].

This article presents the results of tests describing the dynamics of the $\sigma$ phase precipitation process in austenitic steels depending on the ageing time and temperature.

\section{MATERIAL AND METHODOLOGY}

The testing material consisted of new generation Super 304H (X10CrNiCuNb18-9-3), HR3C (X6CrNiNbN25-20) and Sanicro 25 (X7NiCrWCuCoNbNB25-23-3-3-2) austenitic steels. The test samples were taken from finished products in the form of tube sections with the following dimensions: $42.4 \mathrm{~mm} \times 8.8 \mathrm{~mm}$ (Super $304 \mathrm{H}$ steel), $54 \mathrm{~mm} \times 4.4 \mathrm{~mm}$ (HR3C steel) and $38 \mathrm{~mm} \times 8.8 \mathrm{~mm}$ (Sanicro 25). The chemical composition of the tested steel is presented in Tables 1-3.

The microstructural studies were carried out using a scanning electron microscope (Inspect F) on conventionally prepared electrolytically etched metallographic microsections. The studies on microstructure using a transmission electron microscope (TEM) were carried out using thin films.

The quantitative analysis of the $\sigma$ phase precipitation was performed with the use of a computer image analysis system. The image analysis system was calibrated using a scale marker on the photographs of microstructures. The assumed calibration factor was: 1 pixel $=0.040 \mu \mathrm{m}$. The computer image analysis was performed on prepared binary images of the microstructure.

The above-mentioned tests were carried out for the Super 304H and HR3C steels in delivery condition (after solution heat treatment) and after long-term ageing for 1,000, $10,000,20,000,30,000$ and 50,000 hours at $700^{\circ} \mathrm{C}$.

\section{TEST RESULTS AND OVERVIEW}

Characteristic images of the microstructure of the tested steels in delivery condition and after ageing for up to 50,000 hours, observed using SEM, are shown in Figs. 1, 3, 5 , where, based on the tests carried out using TEM (Figs. 2, $4,6)$ and an alloying element distribution map analysis, the areas of $\sigma$ phase precipitation are marked. 

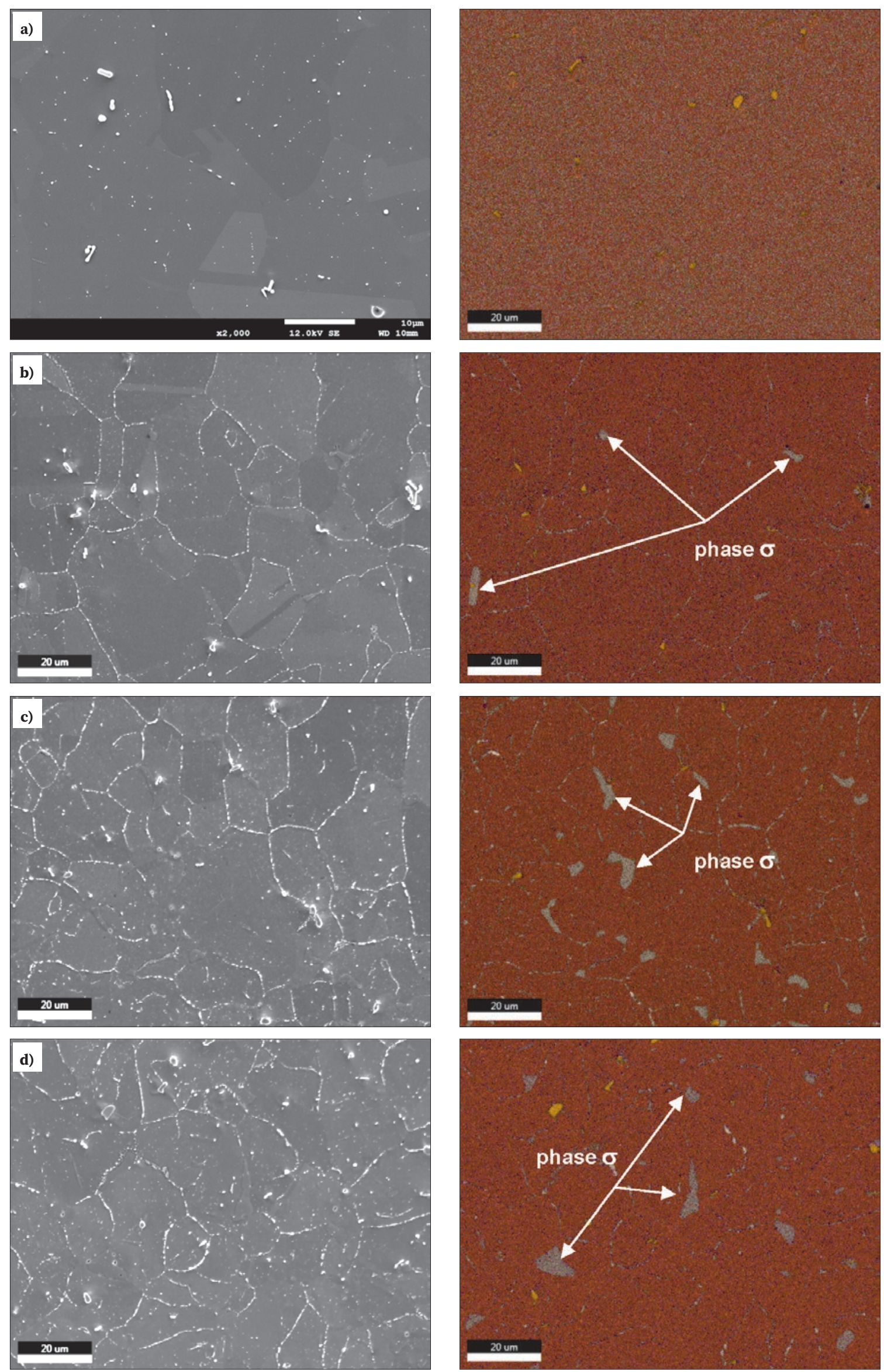

Fig. 1. Microstructure of Super $304 \mathrm{H}$ steel against the alloying element distribution map; a) as delivered, b) ageing $10,000 \mathrm{~h} / 700^{\circ} \mathrm{C}$, c) ageing $30,000 \mathrm{~h} / 700^{\circ} \mathrm{C}$, d) ageing $50,000 \mathrm{~h} / 700^{\circ} \mathrm{C}$

Rys. 1. Mikrostruktura stali Super $304 \mathrm{H}$ na tle mapy rozkładu pierwiastków stopowych; a) stan dostawy, b) starzenie $10000 \mathrm{~h} / 700^{\circ} \mathrm{C}$, c) starzenie $30000 \mathrm{~h} / 700^{\circ} \mathrm{C}$, d) starzenie $50000 \mathrm{~h} / 700^{\circ} \mathrm{C}$ 

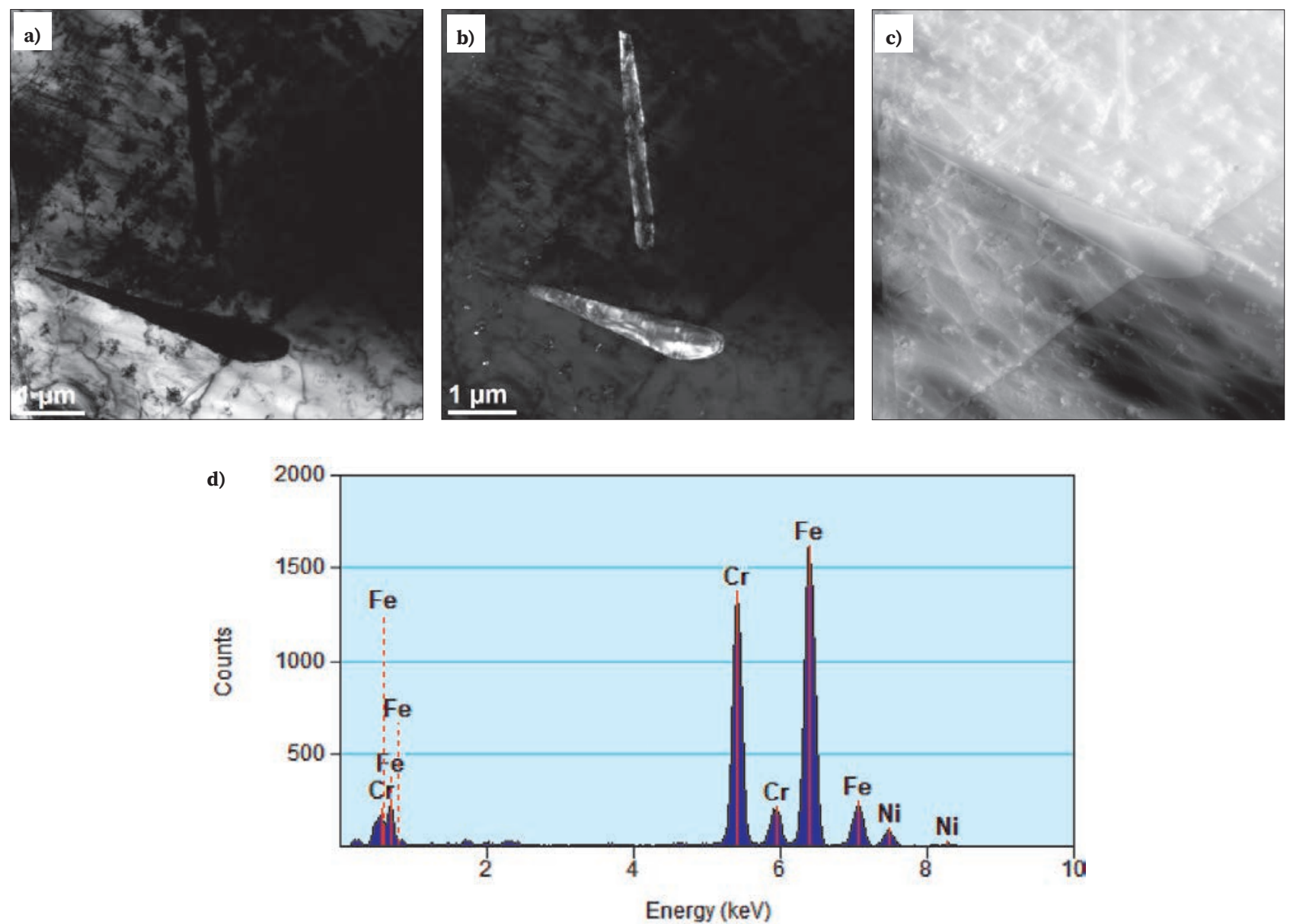

Fig. 2. $\sigma$ phase precipitates inside austenite grain in the Super $304 \mathrm{H}$ steel after 30,000 hours of ageing at $700^{\circ} \mathrm{C}$; a) bright field, b) dark field, c) HAADF-STEM, d) EDS spectrum

Rys. 2. Wydzielenia fazy $\sigma \mathrm{w}$ stali Super $304 \mathrm{H}$ po 30000 godzin starzenia w temperaturze $700^{\circ} \mathrm{C}$; a) jasne pole, b) ciemne pole, c) STEMHAADF, d) widmo EDS

In the tested steels, the $\sigma$ phase precipitates were not found in the samples aged for 1,000 hours. However, the identification of this phase was shown by metallographic tests after an ageing time of $10,000 \mathrm{~h}$ at $700^{\circ} \mathrm{C}$, mainly at grain boundaries. The extension of the ageing time showed an increase in the $\sigma$ phase precipitates along grain boundaries and its precipitation inside austenite grains. The precipitation of the $\sigma$ phase is favoured by an increase in the chromium content in the steel as well as by stabilising carbide-forming elements such as niobium and titanium, since they bind carbon atoms in MX precipitates. In the initial stage of $\sigma$ phase precipitation, they have a wedge shape at grain boundaries and a disc shape inside austenite grains [16]. The initial stage of the precipitation of this phase may have a positive effect on creep strength, while its tendency to grow with increasing temperature and ageing time makes its influence on the functional properties definitely negative [14]. The precipitation of this phase occurs slower than for $\mathrm{M}_{23} \mathrm{C}_{6}$ carbides, because they are incoherent with the matrix and the diffusion of chromium in austenite is slow $[17,18] . \sigma$ phase precipitation reduces the grain boundary energy and redistributes iron and chromium atoms. It is caused by faster diffusion in the area of the defective structure of the boundary than into the interior of the grains. The $\sigma$ phase after longer ageing times is also observed inside austenite grains $[6,16]$. The process of nucleation and growth rate of the $\sigma$ phase precipitates inside the grain is slower compared to the $\sigma$ phase precipitates at grain boundaries. It is related to higher nucleation energy inside the grains than for nucleation at the boundary, and also significantly lower volume of diffusion of the $\sigma$ phase formation than diffusion through grain boundaries $[8,16]$. $\sigma$ phase characterised by high hardness and brittleness, and its precipitation in steels with an austenitic matrix contributes to a decrease in plasticity and ductility. It also reduces the corrosion resistance, which results from the decrease of chromium atoms in the matrix [19-21].

The measurement results for the average equivalent diameter of the $\sigma$ phase precipitates of the tested steels after ageing at $700^{\circ} \mathrm{C}$ for up to 50,000 hours are shown in Fig. 7, while the surface area of the particles' cross-section is shown in Fig. 8.

The presented results of measurement of the average equivalent diameter and the surface fraction of the $\sigma$ phase indicate that its precipitation occurs between 1,000 and 10,000 hours at the ageing temperature of $700^{\circ} \mathrm{C}$. No metallographic studies were carried out in this study within this time frame. However, [22] showed the presence of the $\sigma$ phase after 3,000 hours of ageing. The difficult identification of the $\sigma$ phase in the tested steel is confirmed by its small share in the surface area after 10,000 hours, amounting to approx. $0.15-2 \%$ for the temperature of $700^{\circ} \mathrm{C}$. The increase in the $\sigma$ phase surface area share with the ageing time is consistent with the simultaneous decrease in the 

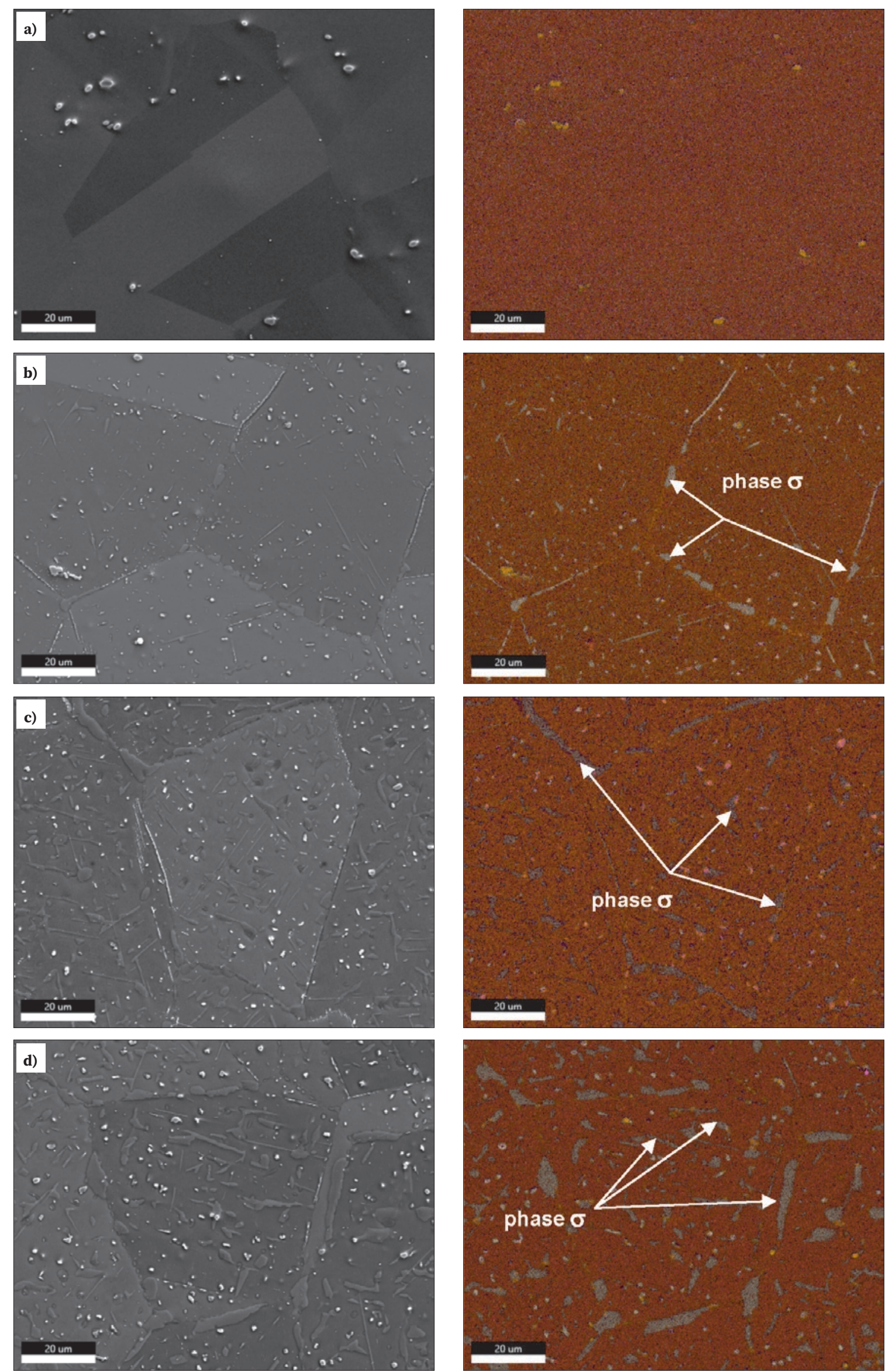

Fig. 3. Microstructure of HR3C steel against the alloying element distribution map; a) as delivered, b) ageing $\left.10,000 \mathrm{~h} / 700^{\circ} \mathrm{C}, \mathrm{c}\right)$ ageing 30,000 $\mathrm{h} / 700^{\circ} \mathrm{C}$, d) ageing $50,000 \mathrm{~h} / 700^{\circ} \mathrm{C}$

Rys. 3. Mikrostruktura stali HR3C na tle mapy rozkładu pierwiastków stopowych; a) stan dostawy, b) starzenie $10000 \mathrm{~h} / 700^{\circ} \mathrm{C}$, c) starzenie $30000 \mathrm{~h} / 700^{\circ} \mathrm{C}$, d) starzenie $50000 \mathrm{~h} / 700^{\circ} \mathrm{C}$ 

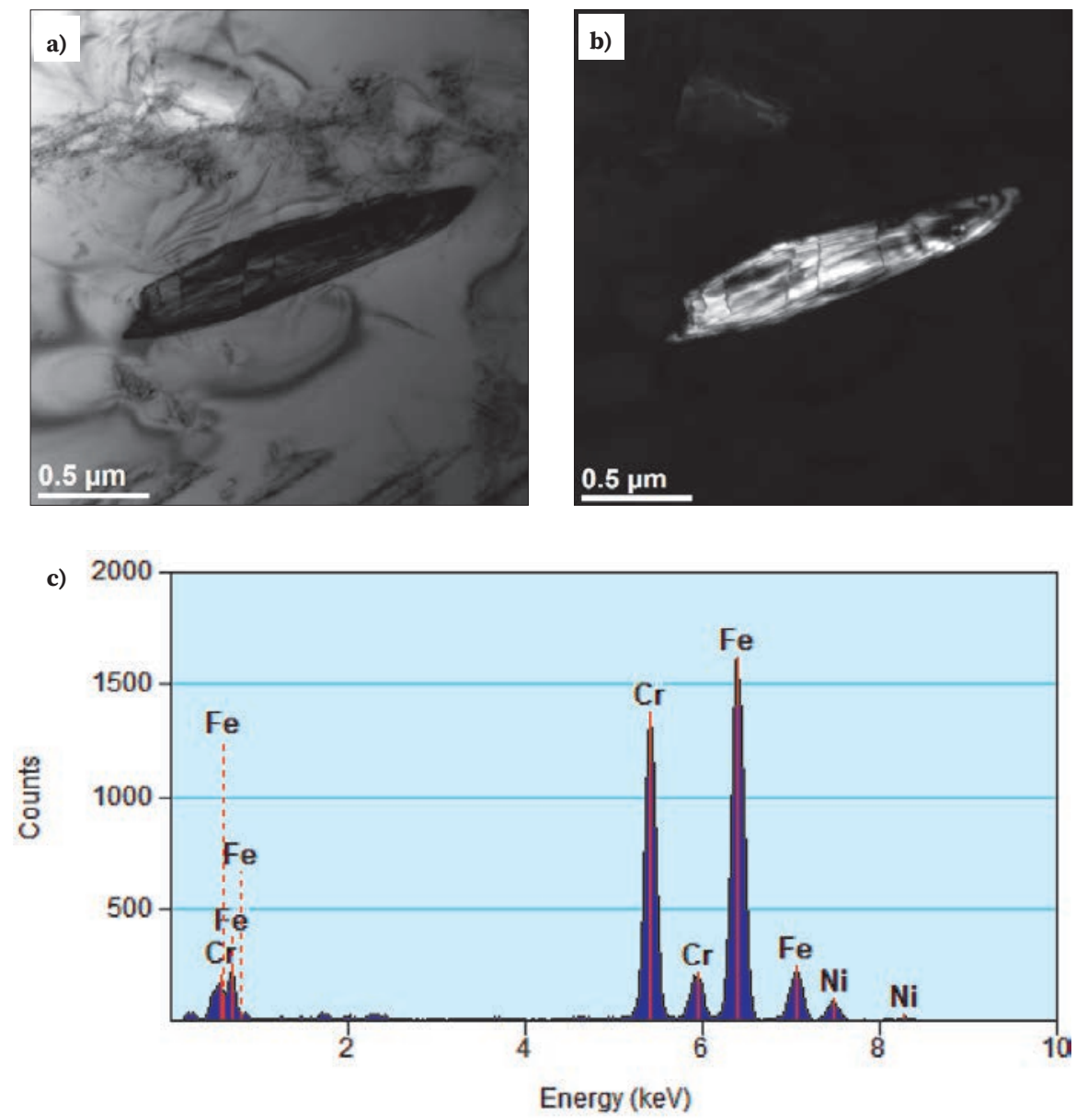

Fig. 4. $\sigma$ phase precipitates inside austenite grain in the HR3C steel after 50,000 hours of ageing at $700^{\circ} \mathrm{C}$; a) bright field, b) dark field, c) EDS spectrum

Rys. 4. Wydzielenia fazy $\sigma \mathrm{w}$ stali HR3C po 50000 godzin starzenia $\mathrm{w}$ temperaturze $700^{\circ} \mathrm{C}$; a) jasne pole, b) ciemne pole, c) widmo EDS

$\mathrm{M}_{23} \mathrm{C}_{6}$ precipitates' surface area share $[2,6]$. The precipitation of the $\sigma$ phase at grain boundaries may be accompanied by the dissolution of the $\mathrm{M}_{23} \mathrm{C}_{6}$ precipitates in the matrix [8]. This is also confirmed by the studies presented in [22].

\section{SUMMARY}

To determine the degree of loss of durability of the tested steels on the basis of changes in the microstructure, it is necessary to know the behaviour of the materials at high temperature over a long period of exposure. The many years of research on this subject show that changes in the microstructure of austenitic matrix steels occur through the precipitation process. These processes cause the loss of service life of steel, while reducing their desired functional properties (mainly heat resistance). The dynamics of the $\sigma$ phase precipitation process, and thus its intensity in the loss of durability, depend on the chemical composition of the matrix and the ageing temperature.

The ageing time above 10,000 hours at $700^{\circ} \mathrm{C}$ revealed the initiation of the adverse effect of the $\sigma$ phase precipitation process, which is manifested by a decrease in creep resistance, an increase in brittleness and an increase in the susceptibility of the tested steels to sensitisation and pitting corrosion [8]. With the extension of ageing time above
10,000 hours, a noticeable increase in the average diameter of the $\sigma$ phase precipitates is observed.

The low thermodynamic stability of these precipitates leads to an increase in their number and size at the boundaries, locally creating a network of precipitates. The increased dynamics of growth and coalescence of the $\sigma$ phase should be deemed to be related to the ageing processes, which are manifested in the loss of coherence with the steel matrix and coagulation of the precipitated particles.

The results of the presented research are not only of cognitive importance, constituting the basis for material characteristics in the perspective of introducing the studied grades to the Polish power industry, but most of all they constitute a significant practical contribution, as they allow the use of the accumulated knowledge in the field of the development of microstructure degradation processes and properties of the tested steels in the prognosis of their operational durability. 

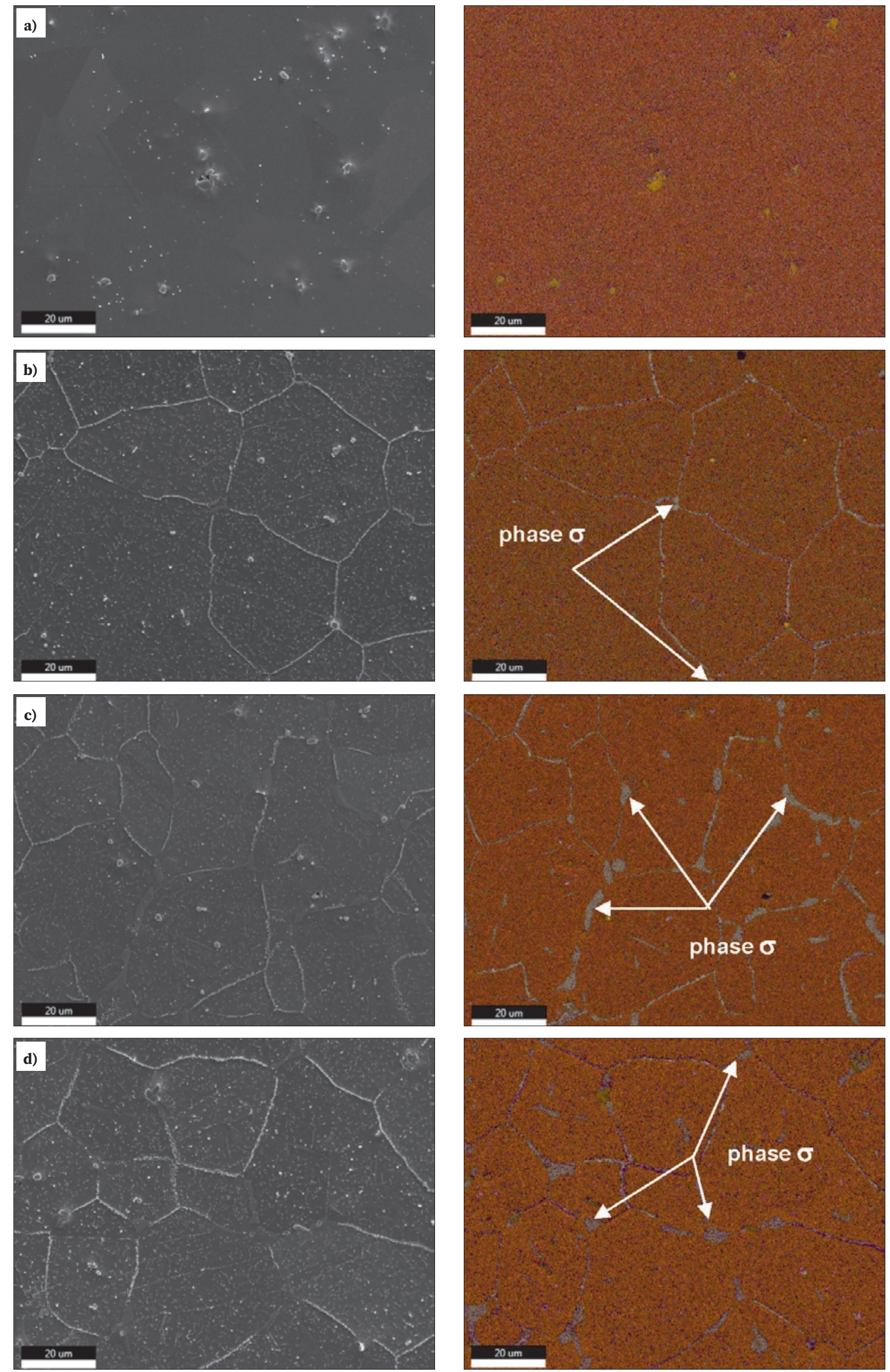

Fig. 5. Microstructure of Sanicro 25 steel against the alloying element distribution map; a) as delivered, b) ageing $10,000 \mathrm{~h} / 700^{\circ} \mathrm{C}$, c) ageing $\left.30,000 \mathrm{~h} / 700^{\circ} \mathrm{C}, \mathrm{d}\right)$ ageing $50,000 \mathrm{~h} / 700^{\circ} \mathrm{C}$

Rys. 5. Mikrostruktura stali Sanicro 25 na tle mapy rozkładu pierwiastków stopowych; a) stan dostawy, b) starzenie $10000 \mathrm{~h} / 700^{\circ} \mathrm{C}$, c) starzenie $30000 \mathrm{~h} / 700^{\circ} \mathrm{C}$, d) starzenie $50000 \mathrm{~h} / 700^{\circ} \mathrm{C}$ 

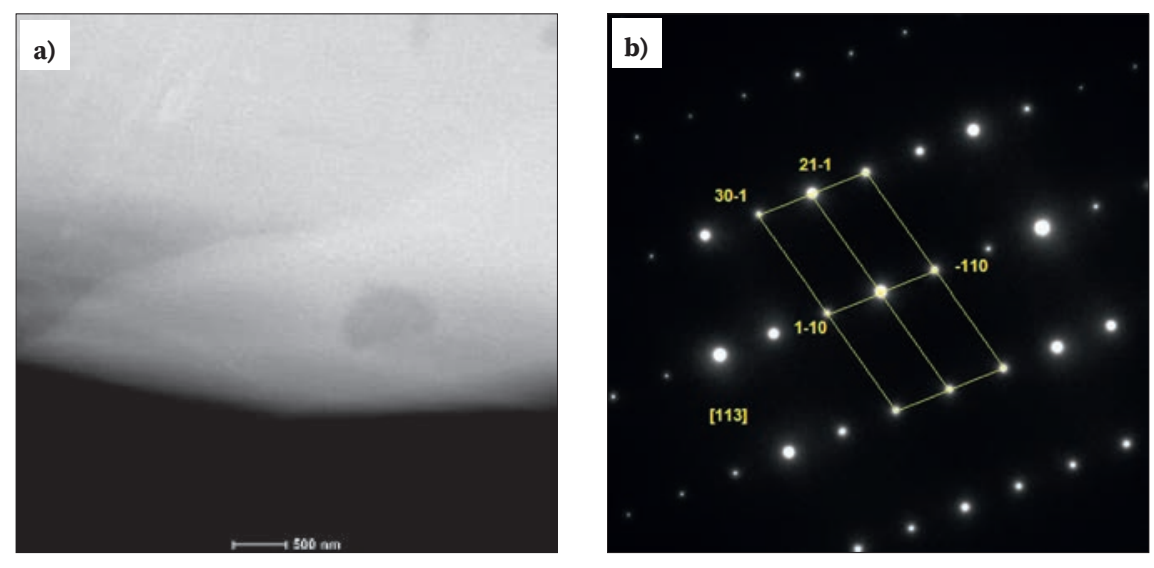

c)

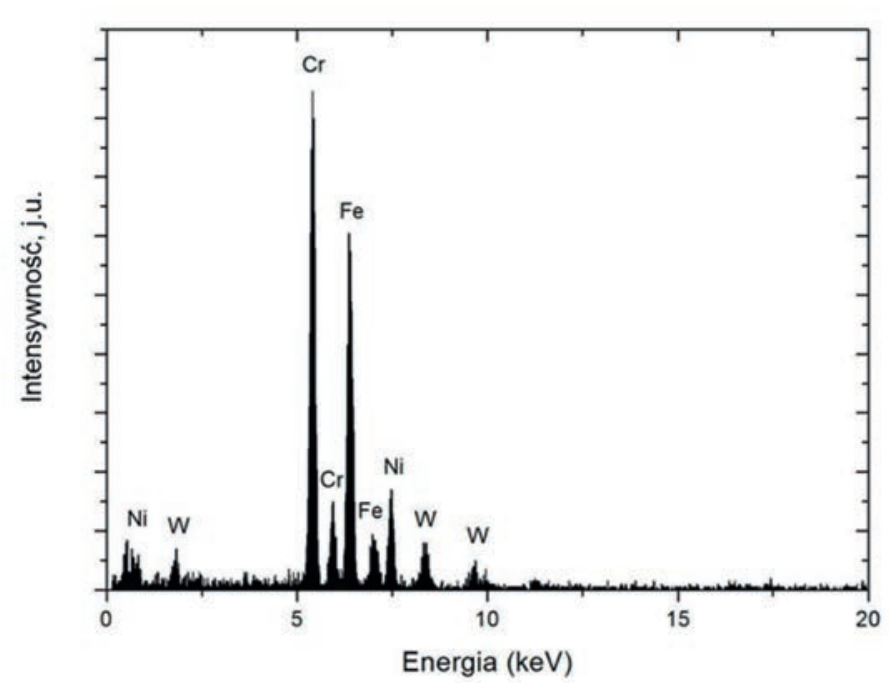

Fig. 6. $\sigma$ precipitate inside austenite grain in the Sanicro 25 steel after 10,000 hours of ageing at $750^{\circ} \mathrm{C}$ : a) bright field, b) solved diffraction pattern from the area in Figure a, c) EDS spectrum; TEM [2]

Rys. 6. Wydzielenie $\sigma$ w stali Sanicro 25 po 10000 godzin starzenia w temperaturze $750^{\circ} \mathrm{C}$ : a) pole jasne, b) rozwiązany dyfraktogram z obszaru na rysunku a, c) widmo EDS; TEM [2]

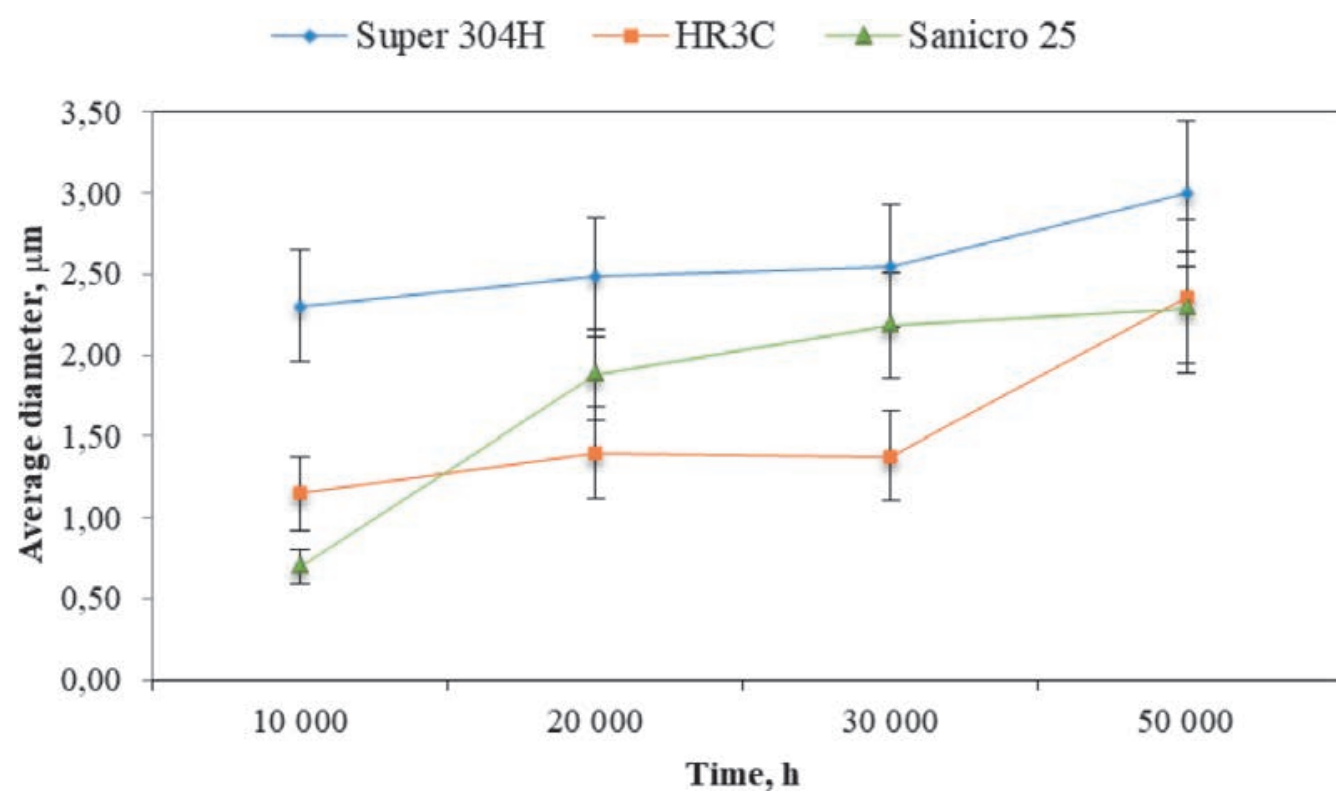

Fig. 7. Results of quantitative analysis of the equivalent diameter of $\sigma$ phase precipitates of the tested steels after ageing at $700^{\circ} \mathrm{C}$ Rys. 7. Wyniki analizy ilościowej średnicy równoważnej wydzieleń fazy $\sigma$ badanych stali po starzeniu w temperaturze $700^{\circ} \mathrm{C}$ 


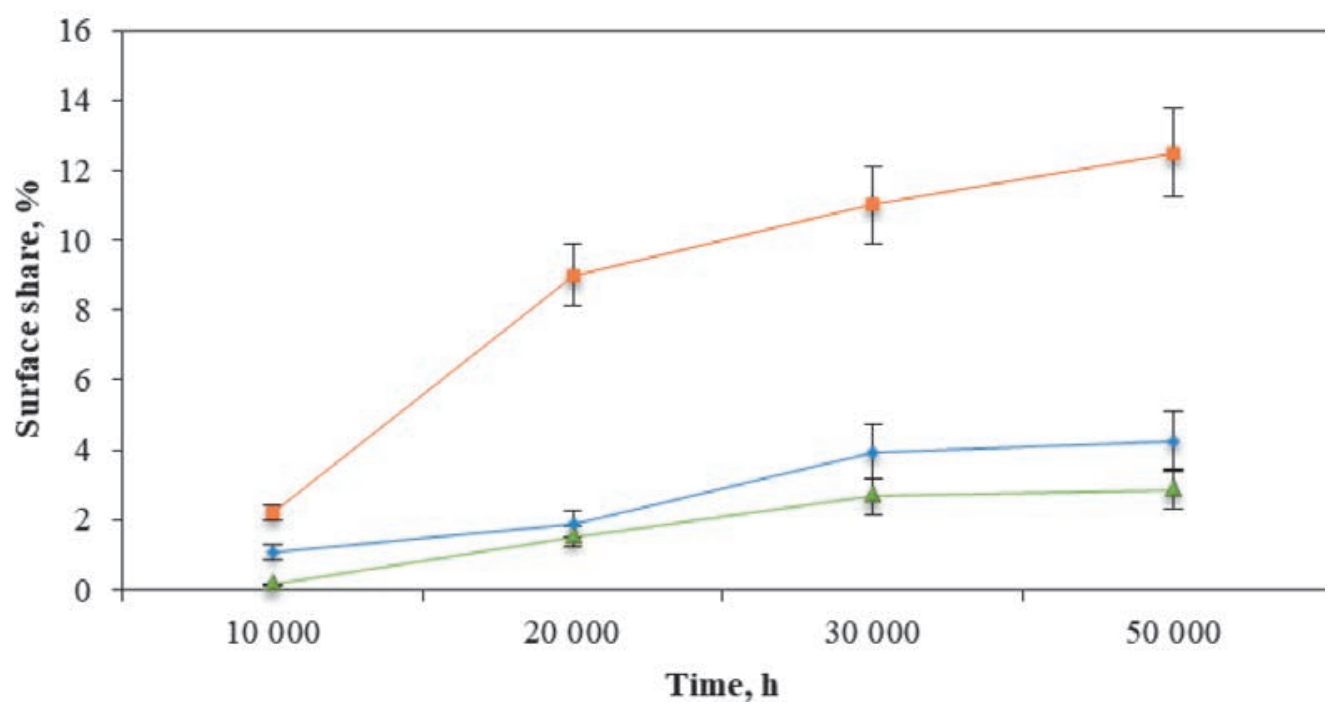

Fig. 8. Results of quantitative analysis of the surface fraction of $\sigma$ phase precipitate surface area of the tested steels after ageing at $700^{\circ} \mathrm{C}$ Rys. 8. Wyniki analizy ilościowej udziału powierzchniowego wydzieleń pola powierzchni fazy $\sigma$ badanych stali po starzeniu w temperaturze $700^{\circ} \mathrm{C}$

\section{REFERENCES}

[1] A. Hernas, J. Dobrzański, J. Pasternak, S. Fudali. Charakterystyki nowej generacji materiatów dla energetyki. Gliwice: Wyd. Pol. Śl., 2015.

[2] M. Sroka. Analiza procesów wydzieleniowych zachodzacych w mikrostrukturze stali Sanicro 25 w temperaturze podwyższonej. Gliwice: Wyd. Instytutu Metalurgii Żelaza, Monografie, No. 13, 2019.

[3] H. Purzyńska, G. Golański, A. Zieliński, J. Dobrzański, M. Sroka. Precipitation study in Ti-stabilised austenitc stainless steel after 207000 h of service. Materials at High Temperatures, 2019, 36 (4), p. 1-8.

[4] M. Sroka, A. Zieliński, G. Golański. Analysis of precipitation in Sanicro 25 austenitic steel after ageing. Acta Physica Polonica A, 2019, 135 (2), p. 207-211.

[5] A. Hernas, B. Kościelniak, I. Bednarczyk. Structural stability of nickel superalloy IN740H after ageing in $750^{\circ} \mathrm{C}$. Journal of Achievements in Materials and Manufacturing Engineering, 2015, 69 (1), p. 5-9.

[6] A. Zieliński, G. Golański, M. Sroka. Evolution of the microstructure and mechanical properties of HR3C austenitic stainless steel after ageing for up to $30,000 \mathrm{~h}$ at $650-750^{\circ} \mathrm{C}$. Materials Science \& Engineering: A, 2020, 796, 139944.

[7] A. Zieliński. Trwałość eksploatacyjna żarowytrzymatych stali o os nowie ferrytycznej $w$ warunkach dtugotrwatego oddziatywania temperatury. Gliwice: Wyd. Instytutu Metalurgii Żelaza, Monografie, No. 7, 2016.

[8] G. Golański. Żarowytrzymate stale austenityczne. Częstochowa: Wyd. Wydziału Inżynierii Produkcji i Technologii Materiałów Politechniki Częstochowskiej, Monografie 73, 2017.

[9] J. Dobrzański, A., Zieliński, J. Pasternak, A. Hernas. Experiments with application of new steels in manufacturing of the components of boilers with supercritical parameters. Prace Instytutu Metalurgii Żelaza, 2010, 62 (1), p. 51-60.

[10] J. Horváth, J. Janovec, M. Junek. The changes in mechanical properties of austenitic creep resistant steels SUPER 304H and HR3C caused by medium-term isothermal ageing. Solid State Phenomena, 2017, 258, p. 639-642.
[11] G. Golański, C. Kolan, A. Zieliński, K. Klimaszewska, A. Merda, M. Sroka, J. Kłosowicz. Microstructure and mechanical properties of HR3C austenitic steel after service. Archives of Materials Science and Engineering, 2016, 81 (2), p. 62-67.

[12] Z. Liang, Q. Zhao, J. Deng, Y. Wang. Influence of Aging treatment on the microstructure and mechanical properties of T92/Super 304H dissimilar metal welds. Materials at High Temperatures, 2018, 35 (4), p. 327-334.

[13] M. Kierat, A. Zieliński. Increased temperature and long-term impact of the ageing process on changes in the microstructure of the HR6W alloy. Journal of Metallic Materials, 2019, 71 (2), p. 8-13.

[14] Y.-S. Ji, J. Park, S.-Y. Lee, J.-W. Kim, S.-M. Lee, J. Nam, B. Hwang, J.-Y. Suh, J.-H. Shim. Long-term evolution of $\sigma$ phase in $304 \mathrm{H}$ austenitic stainless steel: experimental and computational investigation. Mater. Charact., 2017, 128, p. 23-29.

[15] Z. Kuboň, Š. Stejskalová, L. Kander. Effect of Sigma Phase on Fracture Behavior of Steels and Weld Joints of Components in Power Industry Working at Supercritical Conditions. In: W. Borek (Ed.) Austenitic Stainless Steels - New Aspects, IntechOpen 2017, p. 63-92.

[16] M. Farooq. Strengthening and degradation mechanism in austenitic stainless steels at elevated temperature. PhD thesis. Stockholm: Royal Institute of Technology, 2013.

[17] Ch.-Ch. Hsieh, W. Weite. Overview of intermetallic sigma $(\sigma)$ phase precipitation in stainless steels. ISRN Metallurgy 2012 (1), 732471, p. 1-16. doi.org/10.5402/2012/732471.

[18] H. Chen, D. Wang, Y. Yu, K.A. Newton, D.A. Muller, H. Abruna, F.J. DiSalvo. A surfactant-free strategy for synthesizing and processing intermetallic platinum-based nanoparticle catalysts. Journal of the American Chemical Society, 2012, 134 (44), pp. 18453-18459.

[19] G. Golański, A. Zieliński, H. Purzyńska. Precipitation process in creep-resistant austenitic steels. W. Borek (Ed.) Austenitic Stainless Steels - New Aspects, IntechOpen 2017, p. 93-112.

[20] A.F. Padilha, P.R. Rios. Decomposition of austenite in austenite stainless steel. ISIJ International, 2002, 42 (4), p. 325-337.

[21] J. Barcik. Mechanism of $\sigma$-phase precipitation in $\mathrm{Cr}-\mathrm{Ni}$ austenitic steels. Materials Science and Technology, 1988, 4 (1), p. 5-15. 